\title{
Relationship between Economic Development and Intellectual Production
}

\section{Umut Al \& Zehra Taşkın}

To cite this article: Umut Al \& Zehra Tașkın (2015) Relationship between Economic Development and Intellectual Production, Collnet Journal of Scientometrics and Information Management, 9:1, 25-35, DOI: 10.1080/09737766.2015.1027102

To link to this article: https://doi.org/10.1080/09737766.2015.1027102

\section{Published online: 22 Jun 2015.}

\section{Submit your article to this journal $₫$}

山 Article views: 209

Q View related articles $\asymp$

View Crossmark data $₫$

4 Citing articles: 1 View citing articles 


\title{
Relationship between Economic Development and Intellectual Production
}

\author{
Umut Al \\ Zehra Taşkın
}

The level of economic development affects the design of different systems. At the country level, scientific outputs are related to the research and developmentexpenditures.In this study,the relationship between economic development and intellectual production was investigated. In this study following research questions were addressed: 1 . Is there any meaningful relationship between GDP and the number of patents? 2 . Is there any meaningful relationship between GDP and the number of scientific publications? 3. Is there any correlation between R\&D expenditures and patent production? 4 . Is there any correlation between $R \& D$ expenditures and the number of scientific publications? In addition to these research questions, this paper focuses on the changes of economic development and intellectual production indicators throughout time. As a result, it was seen that countries show continuous improvement in years, both for economic development indicators and intellectual production indicators.Findings also showed that Luxembourg, USA, Switzerland, Norway and Israel are far beyond form other countries in terms of national income per person, Scandinavian countries distinctively separated from other countries especially in terms of the number of national patents per population and Switzerland, Sweden, Israel, Denmark and Finland share the first rows in the number of publications per population ranking.
\end{abstract}

Keywords: Economic development, intellectual production, research and development expenditures, scientific outputs.

\author{
Umut Al \\ Zehra Taşkın \\ Deptt. of Information \\ Management \\ Hacettepe University \\ 06800, Beytepe Ankara \\ Turkey \\ umutal@hacettepe.edu.tr \\ ztaskin@hacettepe.edu.tr
}

This paper has been developed based on the paper presented at the $10^{\text {th }} I n$ ternational Conference on Webometrics, Informetrics and Scientometrics $\mathcal{E} 15$ th COLLNET Meeting, held during Sept. 3-5, 2014 at Ilmenau University of Technology, Ilmenau, Germany. 


\section{Introduction}

It is widely accepted that countries' scientific and technological progress and Research and Development (R\&D) expenditures are related to the economic development levels. The measure of development level for countries,at first, had been natural capital, which is about the wealth of natural resources, rich oil deposits, fertile soils, etc. However, productivity of countries, which includes human capital, physical capital and natural capital, has been taking the place of pure natural capital [1]. The measurements of development levels are accepted as GDP (Gross Domestic Products) and GNP (Gross National Products). GDP is defined as the market value of goods and services produced within a selected geographic area (usually a country) in a selected interval of time (often a year). It is generally about outcomes rather than processes. Although GNP has similar meaning with GDP, multinational corporations are only calculated by GDP. GNP is a more local quantity[2].

Developed countries have large investments on R\&D. At the same time, their scientific and intellectual production has been increasing year by year. The most important issues of science policy in each country are the structure and efficacy of R\&D activity and its relation to GDP [3].The challenges in cross-national comparisons of R\&D expenditure and publication output were also reported in the literature [4].It is also mentioned that some factors, such as the coverage and comparability of countries in the Web of Science, differences in national research systems, may affect the validation and comparison [4].

With this study, the relationship between the indicators of economic development (R\&D expenditures, GDP) and intellectual production (number of national and triadic patents, and number of scientific publications) was investigated.

\section{Literature Review}

There are too many publications in the literature that point out the relationship between GDP and science and technology production and expenditures. One of the prior works about this relationship was written by Teitel in 1994 [5]. He used mathematical methods to calculate the relationship, and found statistically significant and meaningful results between patents, R\&D expenditures, country sizes and per-capita incomes.

Ye's study [6] found the strongest relationship between country development level and scientometric criteria. The correlation between GDP and scientific production was determined for 24 countries by using IMF, WIPO and UNESCO data. However, the author indicated that the results of study were based on only one year-data (2001) and further studies wereneeded to confirm these results.

Another study in the literature presented a model to test the relationship between $R \& D$ expenditures and number of patents, by evaluating case studies in the literature [7]. As a result, a strong positive correlation determined between $R \& D$ expenditures and patent applications was found. In addition to this, it was pointed out that the numbers of patents also differ from country to country. 
A report [8] indicated that levels of R\&D spending were interrelated to levels of economic growth. Findings showed that $R \& D$ intensities were temporarily influenced by the levels of GDP growth. However, the development patterns differ strongly among the countries depending on governance structure, policy priorities, and systematic features like industry and academic structures, which means "one size fits all" approach doesnot fit for all the countries.

A new indicator to analyse mean structural differences of different fields was found out in another study [3]. A meaningful correlation was determined between GDP and number of publications in the longitudinal studies for countries. However, no direct relationship between GDP and information production of countries was found. It was noted in this study that R\&D expenditures actually did not depend on real needs.However, one should note that,rich countries can always afford to spend more money on scientific researchthan poor countries.

Olwan[9] focused on the correlation between intellectual property systems (IP systems) of countries and their development levels. This paper investigated developing countries from the point of effectiveness of their IP systems and its effects to their economies. As a result, it was found that there was no meaningful correlation between IP systems and economic development levels of developing countries.

Some studies in the literature concentrated on different effects of scientific outputs. Inone of these studies [10], scientific output and its relationship with knowledgeeconomy were examined in 10 South East Asian countries. This study [10] found that there was a strong relationshipbetween scientific output and knowledge economy index among the South East Asian countries. In a more recent study [11], the empirical relationship between educationalindicators and research productivity in top twenty nations of the world in terms of number of publications, citations and patents was examined.The results revealed that educational indicators wereimportant to increase research productivity.

Many previous studies also found that there can be meaningful correlations between economic power and information production. However, it should not to be forgotten that these kinds of evaluations can change from country to country. The situation for The Organisation for Economic Co-operation and Development (OECD) countries is investigatedby this study.

\section{Methodology and Data Sources}

This study analyses the related data belong to 34 OECD countries. The main aim of this research is to understandthe relationshipbetweenthe indicators of economic developmentand intellectual production. The term "intellectual production" in this study is defined as the number of publications and patents. Patents were also examined according to their types, which were national and triadic. "Economic development" indicators were identified asR\&D expenditures and GDP.It would be interesting to see that whether different development levels of countries affect intellectual production. To achieve the aim of this paper, the following research questions areinvestigated: 
- Is there any meaningful relationship between GDP and the number of patents (national and triadic)?

- Is there any meaningful relationship between GDP and the number of scientific publications?

- Is there any correlation between R\&D expenditures andpatent production?

- Is there any correlation betweenR\&D expenditures and the number of scientific publications?

All of the OECD countries were selected to test correlations. GDP per capita, R\&D expenditures, and number of patents dataweregathered fromOECDiLibrary'sNational Accounts, Main Science and Technology Indicators and OECD Patent Statistics databases (http:/ / www.oecd-ilibrary.org).The number of scientific publications was collected from Thomson Reuters' InCites. The 34 members of OECDwere very different than the others, in terms ofpopulation size. Therefore, all of the indicators were normalized according to population size. The population statistics were also obtained from OECD databases. The data of thestudy showed normal distribution after the normalization process, so the Pearson's correlation analysis was chosen for the correlation tests.To be able to use the Pearson's correlation analysis,median values of all indicators were calculated. Moreover, economic development and intellectual production indicators within a 30-years period (1981-2010) were also analysed within the scope of this study.

\section{Findings}

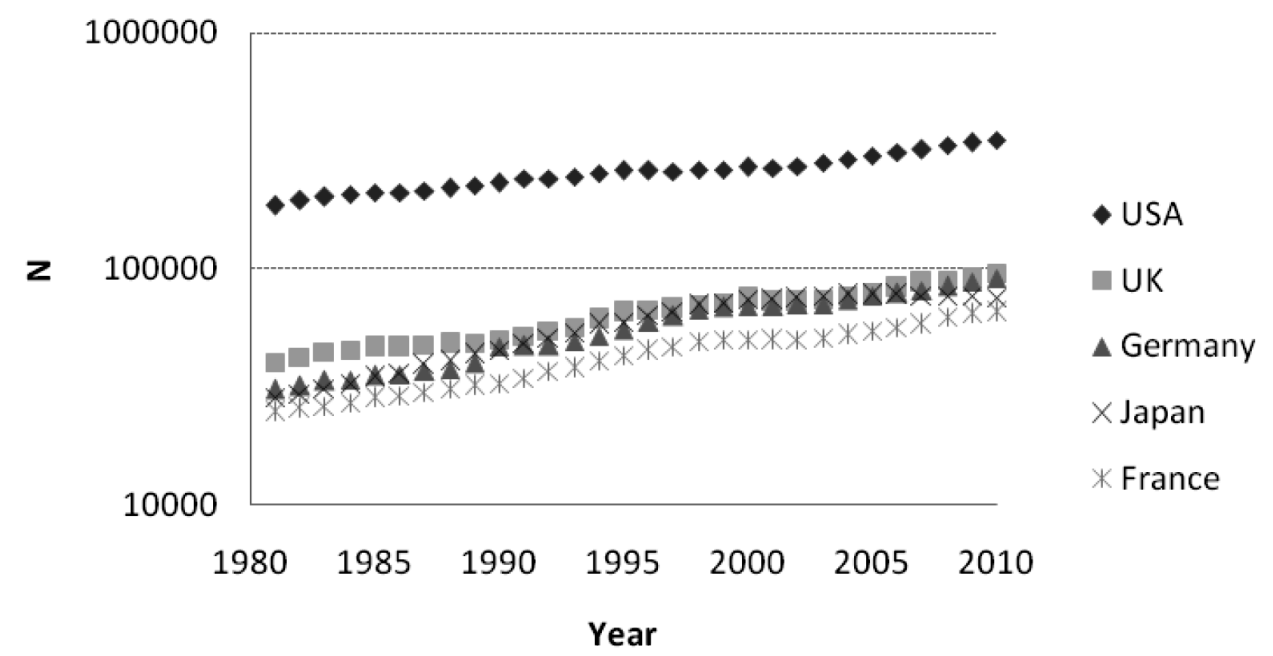

Figure 1

The five most productive countries by year 
Table 1

Number of publications by periods

\begin{tabular}{|c|c|c|c|c|c|c|}
\hline \multirow[b]{2}{*}{ Countries } & \multicolumn{6}{|c|}{ Periods } \\
\hline & 1981-1985 & 1986-1990 & 1991-1995 & 1996-2000 & 2001-2005 & 2006-2010 \\
\hline Australia & 57,003 & 64,710 & 80,299 & 105,033 & 124,051 & 178,197 \\
\hline Austria & 15,721 & 18,099 & 23,432 & 33,888 & 42,152 & 52,999 \\
\hline Belgium & 24,162 & 27,977 & 36,265 & 48,874 & 59,658 & 78,829 \\
\hline Canada & 116,329 & 142,088 & 165,738 & 173,180 & 194,304 & 261,703 \\
\hline Chile & 3,730 & 4,970 & 6,366 & 8,580 & 12,968 & 21,299 \\
\hline Czech Republic & 3 & 221 & 7,678 & 20,804 & 26,852 & 40,551 \\
\hline Denmark & 20,498 & 23,258 & 29,680 & 37,546 & 42,780 & 53,720 \\
\hline Estonia & 4 & 19 & 1,112 & 2,683 & 3,376 & 5,621 \\
\hline Finland & 15,909 & 19,060 & 25,802 & 34,855 & 40,435 & 47,907 \\
\hline France & 132,255 & 155,129 & 193,356 & 241,844 & 258,656 & 307,133 \\
\hline Germany & 165,666 & 197,023 & 251,162 & 328,050 & 361,529 & 423,944 \\
\hline Greece & 6,062 & 9,240 & 14,347 & 22,070 & 33,159 & 50,123 \\
\hline Hungary & 14,676 & 14,746 & 15,200 & 19,193 & 22,824 & 27,225 \\
\hline Iceland & 362 & 557 & 1,038 & 1,457 & 2,077 & 3,243 \\
\hline Ireland & 5,389 & 6,451 & 8,539 & 12,662 & 17,187 & 28,684 \\
\hline Israel & 29,505 & 33,540 & 39,046 & 47,096 & 52,838 & 59,191 \\
\hline Italy & 59,818 & 78,038 & 112,544 & 151,205 & 186,869 & 243,143 \\
\hline Japan & 156,819 & 205,040 & 271,717 & 346,284 & 381,107 & 383,844 \\
\hline Korea & 2,025 & 5,766 & 17,592 & 52,950 & 105,304 & 171,983 \\
\hline Luxembourg & 132 & 131 & 253 & 408 & 713 & 1,866 \\
\hline Mexico & 5,344 & 7,108 & 11,590 & 21,327 & 31,172 & 43,782 \\
\hline Netherlands & 43,218 & 57,910 & 77,438 & 94,728 & 108,303 & 141,569 \\
\hline New Zealand & 12,137 & 13,334 & 15,905 & 21,379 & 24,551 & 33,165 \\
\hline Norway & 13,247 & 14,676 & 19,136 & 24,041 & 28,787 & 42,801 \\
\hline Poland & 24,621 & 28,511 & 32,039 & 44,412 & 63,356 & 89,239 \\
\hline Portugal & 1,700 & 3,341 & 6,554 & 12,948 & 22,790 & 39,335 \\
\hline Slovak Republic & 2 & 71 & 4,535 & 10,366 & 10,377 & 13,894 \\
\hline Slovenia & 1 & 25 & 2,326 & 6,064 & 9,129 & 14,845 \\
\hline Spain & 24,180 & 41,269 & 67,972 & 104,109 & 136,859 & 202,237 \\
\hline Sweden & 40,932 & 49,107 & 59443 & 74,151 & 81,914 & 95,030 \\
\hline Switzerland & 36,058 & 40,301 & 52635 & 67,649 & 77,618 & 102,996 \\
\hline Turkey & 2,014 & 3,865 & 9175 & 22,249 & 53,971 & 97,619 \\
\hline UK & 219,062 & 241,188 & 289777 & 352,238 & 375,505 & 450,002 \\
\hline USA & $1,000,825$ & $1,102,604$ & 1245611 & $1,318,469$ & $1,416,532$ & $1,660,017$ \\
\hline
\end{tabular}


Today, OECD has 34 member countries [12]. It was seen that within the 30-years period that we have dealt in this study, these countries progressed at various levels, in terms of the GDP, R\&D expenditures,number of patents, and number of scientific publications indicators. There is no doubt that this progress should be considered as normal.However, the number of publications had been increased enormously within the years (Figure 1\& Table 1). Although this can be based on the regional development policy of citation indexes [13], there can be also different reasons for each country.

In Table 1, the number of publications of the 34 countries for a six period of five-year intervals was given. These numbers showed that the number of publications of the countries has been increasing over time. Although such amount of increase was not observed, it is known that the number of patents was also escalating. In addition to this, a substantial increase in the share of $R \& D$ expenditures and national incomes of the countries was also recognized. To be able to make meaningful comparisons, population information of the countries was used.

In Figure 2, the relationship between the number of publications per 1000 people and GDP per head was shown in the country level. The numbers in the Figure represents the median values of the 30-years data. Scandinavian countries (such as, Sweden, Denmark, Finland) were recognized in the Figure, in terms of both for the number of publications per 1000 people and GDP per head. Along with these countries, Switzerland and Israel were also came to the forth, in terms of the number of publications per population. On the other handLuxembourg, which has the highest national income, located in the bottom of

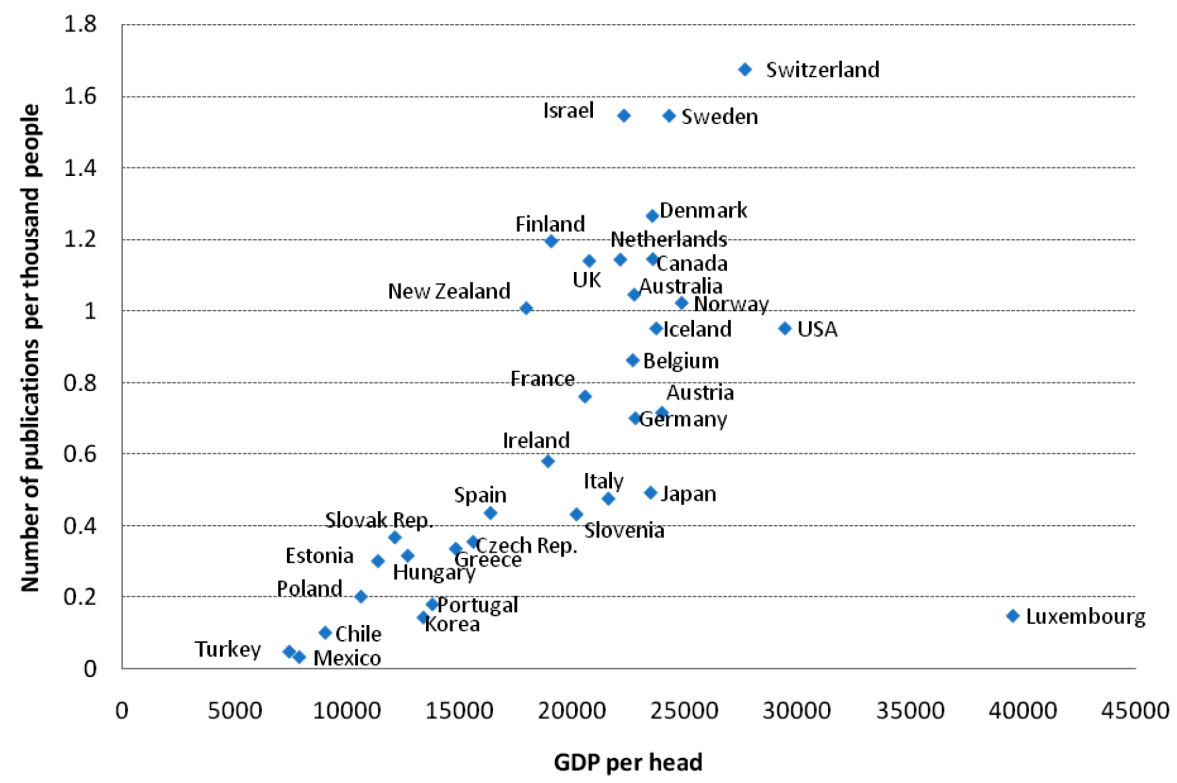

Figure 2

Number of publications per thousand people and GDP per head 


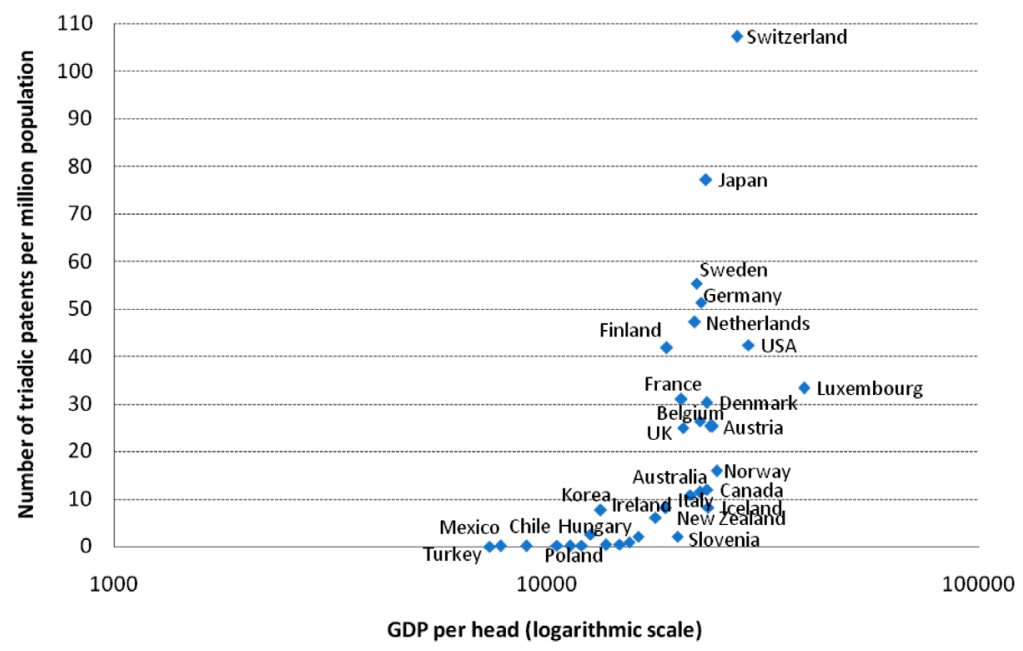

Figure 3

Number of triadic patents per million population and GDP per head

the list in terms of the number of publications per population, like Mexico, Turkey, Chile and Korea. In general, it was observed that, the countries which have the highest number of publications per 1000 peoplehave also the highest GDP per head.

Switzerland, Japan, Sweden, Germany, Netherlands, USA and Finland are leading countriesin terms of the number of triadic patent per country population. Turkey and Mexico has the worst performance in terms of the number of triadic patents per million population along with Estonia, Chile, Poland, Slovak Republic, Portugal, Greece and Czech Republic. These countries have less than one triadic patent per million population (Figure 3).

Luxembourg, Israel, Sweden, USA and Japan are the first five countries that have the highest R\&D expenditures per person (Figure 4). The general trend shows that the countries (such as, Mexico, Turkey, Chile) that has limited shares for R\&D expenditures has also the lowest numbers of publications per population.

In this study the values that were obtained from the division of R\&D expenditures to triadic patent numbers were also compared. In other words, we tried to see the amount of money that the countries spend for triadic patents. It was found out that, Switzerland, Japan, Netherlands, Germany and Finland are the most remarkable countries in terms of the ability to transform the R\&D expenditures to patents. Contrary to this, it was identified that Estonia, Turkey, Chile, Mexico and Poland are the ones which spent the most money to have a triadic patent. Figure 5 revealed that R\&D expenditures per population and the number of triadic patents per million population are similar to each other.

Some statistical tests were conducted on the raw data that forms Figure 2, 3, 4 and 5.According to this, significant correlations were observed amongall of theeconomic development indicators and all of the intellectual production indicators (Table 2). 


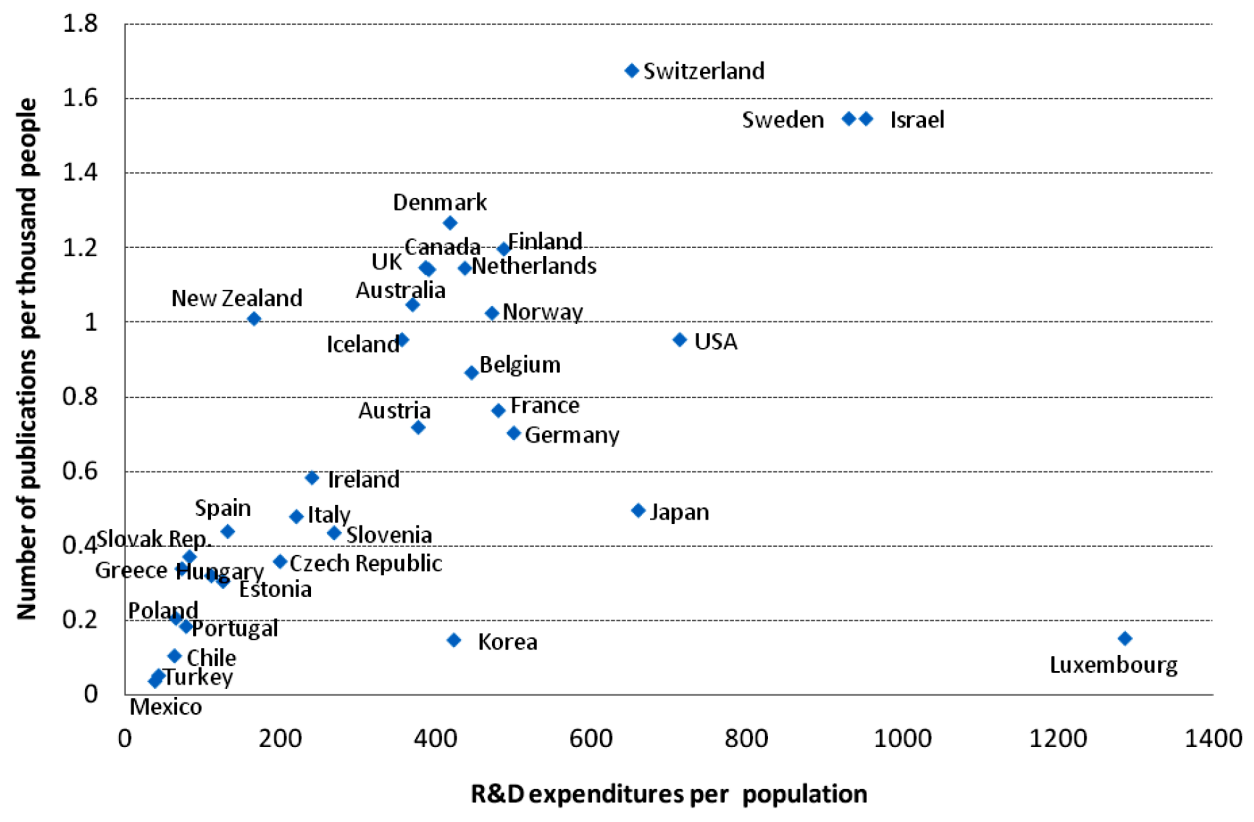

Figure 4

Number of publications per thousand people and R\&D expenditures perpopulation

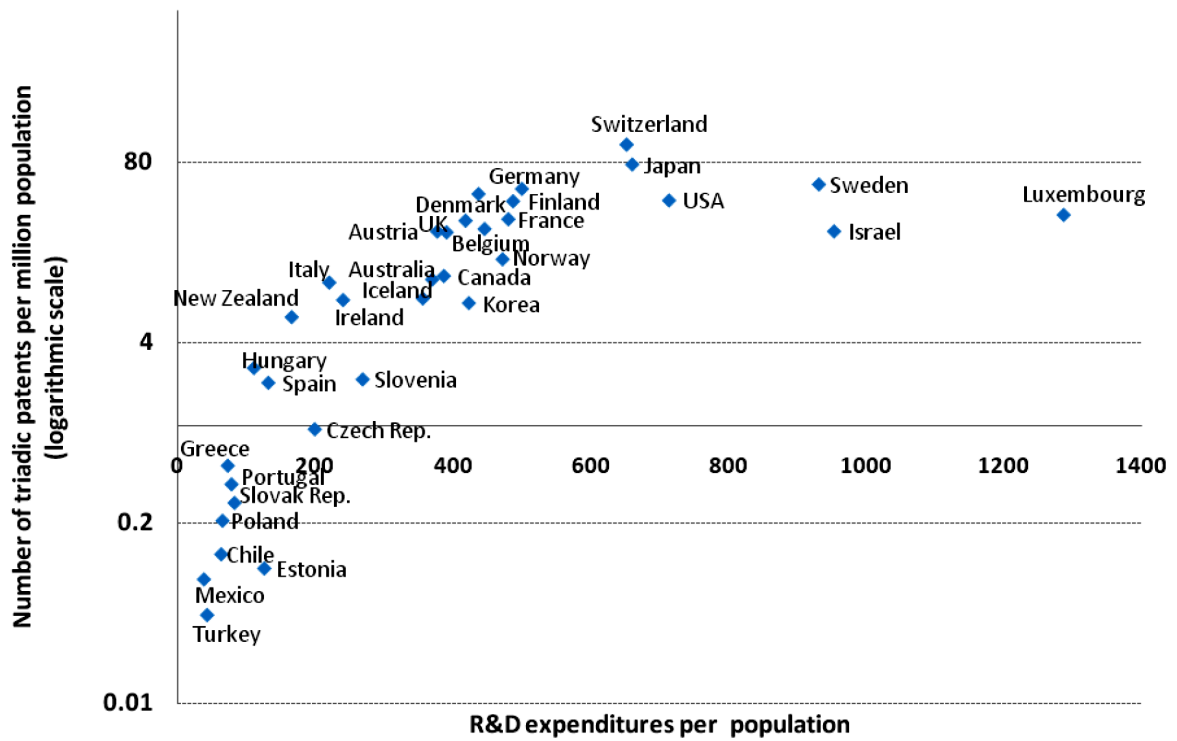

Figure 5

Number of triadic patents per million populationand R\&D expenditures perpopulation 
Table 2

Pearson correlation coefficients among variables

\begin{tabular}{|l|l|l|l|}
\hline \multicolumn{1}{|c|}{$\begin{array}{c}\text { Economic } \\
\text { development } \\
\text { indicators }\end{array}$} & $\begin{array}{c}\text { Number of } \\
\text { publications per } \\
\text { population }\end{array}$ & $\begin{array}{c}\text { Number of triadic } \\
\text { patents per million } \\
\text { population }\end{array}$ & $\begin{array}{c}\text { Number of national } \\
\text { patents per million } \\
\text { population }\end{array}$ \\
\hline GDP per head & 0.561 & 0.604 & 0.567 \\
\hline $\begin{array}{l}\text { R\&D expenditures per } \\
\text { population }\end{array}$ & 0.524 & 0.667 & 0.674 \\
\hline
\end{tabular}

Note: Correlations are significant at the 0.01 level.

In the light of the statistical evaluations, the answers of our research questions are as follows:

- There is a positive correlation between GDP per head and thenumber of publications per population was statistically significant (Pearsons's $r=.561, p<.01$ ).

- There is a positive correlation between GDP per head and the numberof triadic patents per million population was statistically significant (Pearsons's $r=.604, p<.01$ ).

- There is a positive correlation between GDP per head and the numberof national patents per million population was statistically significant (Pearsons's $r=.567, p<.01$ ).

- There is a positive correlation betweenR\&D expenditures per population and the number of publications per population was statistically significant (Pearsons's $r=$ $.524, p<.01)$.

- There is a positive correlation betweenR\&D expenditures per population and the number of triadic patents per million population was statistically significant (Pearsons's $r=.667, p<.01)$.

- There is a positive correlation betweenR\&D expenditures per population and the number of national patents per million population was statistically significant (Pearsons's $r=.674, p<.01)$.

\section{Conclusion}

The relevant investments showthe importance given by the countries to science and R\&D. There is no doubt that scientific productivity level of the countries is affected by not only qualified manpower but also by the economic development levels. Today, parallel to the increase of the importance of knowledge as an economic value, it is witnessed that most of the countries increase their investments for the production of theoretical knowledge which is aimed to be transformed to product and services and develop some new policies towards this goal. Patents and scientific publications, which are the products of labour-intensive work, clearly show the level of investments of the countries for science and 
scientists. From this point, it can be said that competitive advantage of the countries is also parallel to their productivity level of information. From a systems approach perspective, when we take the expenditures as an input, the cost of patents and scientific publications, which can be counted as outputs, must be questioned.

With this research, it is seen that most of the "rich countries" make some important contributions to the world literature, in terms of publications and patents.In this context, some results of this study are similar to the literature. The correlation was observed between GDP per head, R\&D expenditures per population, number of publicationsper population,number of national patents per million population and number of triadic patents per million population.

Country-based findings that we obtained from this research are as follows:

- It was seen that countries show continuous improvement in years, both for economic development indicators and intellectual production indicators.

- Luxembourg, USA, Switzerland, Norway and Israel are far beyond the OECD countries such as Hungary, Slovak Republic, Estonia, Poland, Chile, Mexico and Turkey in terms of national income per person. Similar situation is observed for the R\&D expenditures of the countries. R\&D expenditures of Luxembourg, Israel, Sweden, USA and Japan per person are 10 to 25 -fold higher than that of Greece, Poland, Chile, Turkey and Mexico.

- Scandinavian countries such as Sweden, Finland, Denmark,distinctively separated from other countries especially in terms of the number of national patents per population.Switzerland and Japan are two leading countries in terms of the number of triadic patents per population.

- Switzerland, Sweden, Israel, Denmark and Finlandshare the first rows in the number of publications per population ranking, where Luxembourg, Korea, Chile, Turkey and Mexico are in the bottom among the 34 OECD countries.

Such topics like, the effect of the number of researchers in the countries to the number of research outputs, the contribution of the universities to the national intellectual production, the effects of patents to science, technology and innovation policies of the countries can be considered for the future studies.

\section{References}

[1] Soubbotina, T.B. \& Sheram, K.A. "Beyond economic growth: Meeting the challenges of global development" Washington DC: World Bank, 2000

[2] Leamer, E.E. "Macroeconomic patterns and stories: A guide for MBAs" Heidelberg: Springer, 2009

[3] Vinkler, P. “Correlation between the structure of scientific research, scientometric indicators and GDP in EU and non-EU countries"Scientometrics. 2007, 74, pp. 237-254 
[4] Wendt, K., Aksnes, D.W.,Sivertsen, G.,\&Karlsson, S. “Challenges in cross-national comparisons of R\&D expenditure and publication output" Proceedings of 17th International Conference on Science and Technology Indicators. 2012, pp. 826-834. Montréal: Science-Metrix and OST

[5] Teitel, S. "Patents, R\&D expenditures, country size, and per-capita income: An international comparison"Scientometrics. 1994, 29, pp. 137-159

[6] Ye, F.Y. "A quantitative relationship between per capita GDP and scientometric criteria"Scientometrics. 2007, 71, pp. 407-413

[7] Prodan, I. "Influence of research and development expenditures on number of patent applications: Selected case studies in OECD countries and Central Europe, 1981-2001" Applied Econometrics and International Development. 2005, 4-5, pp. 5-22

[8] IDEA Consult. "A time series analysis of the development in national R\&D intensities and national public expenditures on R\&D"Final Study Report for Specific Assignment 4 (SPA4): Literature Review, Feasibility Study, Collection of Field Statistics, Calculation of Indicators, Survey, Conclusions. http:/ / ec.europa.eu/invest-in-research/pdf/download_ en/spa4_final_report_final.pdf

[9] Olwan, R.M. "Intellectual property and economic development" Intellectual Property and Development. 2013, pp. 99-151.Berlin: Springer Verlag

[10] Nguyen, T.V.\& Pham, L.T. “Scientific output and its relationship to knowledge economy: an analysis of ASEAN countries" Scientometrics. 2011,89, pp. 107-117

[11] Akhmat, G., Zaman, K.,Shukui, T., Javed, Y.\& Khan, M.M. “Relationship between educational indicators and researchoutcomes in a panel of top twenty nations: Windows ofopportunity" Journal of Informetrics. 2014, 8, pp. 349-361

[12] OECD“Members and partners”, 2014,http://www.oecd.org/about/membersandpartners /

[13] Testa, J. “Regional content expansion update: Web of Science 5.0.", 2008, http:/ / wokinfo.com/ media/pdf/RExEssay.pdf 